\title{
Latvian public service broadcasting (PSB) at a media policy crossroads on the path to public service media (PSM)
}

\begin{abstract}
This paper critically examines Latvian media policy from the point of view of public value theory, regarding the management of public service media. Since 1992, Latvian Television (LTV, 1954) and Latvian Radio (LR, 1925) officially, i.e. according to law, are independent public service media organisations, and consequently two legal entities. In fact LTV and LR are two state enterprises with one supervising council (five members) elected by parliament according to political proportionality - National Electronic Mass Media Council (the NEPLP). Since 2011, the Latvian government has been slowly deciding plans for the reform and creation of a unified PSM corporation, not just a PSB, i.e. including not only radio and TV broadcasting but a multimedia approach, especially on the Internet platform, due to media convergence. Political decisions of government and parliament for the above-mentioned intent are still wanted. Also, an initiative by LTV and NEPLP to establish a Russian language TV channel was not taken further by decision makers.
\end{abstract}

Key words: public service broadcasting, public service media, public value theory, theory of communicative action, media policy

\section{Introduction}

$\mathrm{T}$ the process of transformation from state broadcasters into public service broadcasting (PSB), and most recently into public service media (PSM), two issues are seen as crucial. Firstly, good knowledge and acceptance of established PSM principles by media policy makers, inter alia facilitating a sense of national identity and cultural belonging, developing public value ${ }^{1}$ also in online and mobile cross-media platforms by

${ }^{1}$ According to the pattern of the British Broadcasting Company (BBC) one can see "public value in five main ways: Democratic value..., Cultural and creative value..., Educational value..., Social and community value..., Global value... These are the BBC's public purposes" (BBC, 2004, p. 8). 
applying and promoting economic measurement (Lowe, Martin, 2014, pp. 20-25). ${ }^{2}$ Secondly, the political will and power to implement those principles of PSM (Beitika, 2015, pp. 87-88). This cognition has been confirmed through the negative Latvian experience with the lack of political support for PSB/PSM (Lowe, Martin, 2014, p. 88).

On one hand, a key element of public value theory, according to the strategic triangle of Mark $\mathrm{H}$. Moore, is the building and sustaining a coalition of stakeholders, called the Authorising Environment, in addition to Public Value Outcomes and Operational Capacity (Benington, Moore, 2011, p. 6). The consensus-oriented theory of communicative action (Habermas, 1976, pp. 174-175; Habermas, 1981, p. 439), on other hand, inter alia anticipates the common interests of the partners of a dialogue, in our case constantly involving the stakeholders of the PSM in dialogue (Troxler, Süssenbacher, Karmasin, 2011, p. 140). This article is based on the author's participatory observation as a Member since 2012 of the National Electronic Mass Media Council (the NEPLP, see Neplpadome.lv), which makes it possible to analyse and compare Latvian practice within that theoretical framework, improving the theoretical research perspective (Dimants, 2008, p. 461) with the unique added value of empirical knowledge.

\section{The state of Latvian PSB and its supervision}

Since 1992, Latvian Television (LTV) ${ }^{3}$ and Latvian Radio (LR $)^{4}$ have been officially, i.e. according to law, independent public service media organisations, comprising two independent legal entities. LTV with its two channels is the third largest player on the local TV market alongside two private ones, firstly, the Swedish MTG Group (channels TV3, LNT etc.) and, secondly, the Russian First Baltic Channel (Dimants, 2012).

2 “... it is important for PSM to demonstrate that the money invested in the enterprise and spent on production and distribution constitutes a fair deal. The resource is public money and that is increasingly scarce. Yet it is equally obvious that delivering value for money cannot legitimate PSM's overall role and functions because these are not primarily about economic criteria and industrial priorities. Of utmost importance is ensuring that its output and outcomes deliver value that is appreciated by its public, and add value to the public sphere. That is the foundational heuristic of public value theory..." (ibid., p. 22).

3 Established in 1954 as the oldest TV station in Baltic States, see LTV.lv.

${ }^{4}$ Established in 1925, see Latvijasradio.lv. 
LTV1 as the first channel is a major channel in the Latvian language while LTV7 is a niche channel with some news and discussion programmes in the Russian language, too.

There are actually two linguistically different markets in Latvia (Latvians and the Russian speaking minority). LR leads in both Latvian and the Russian language radio markets and broadcasts on six stations: LR1 as news and talk radio, LR2 as Latvian popular music radio, LR3 as classical music radio, LR4 as Russian language radio, LR5-Pieci.lv as youth radio and LR6 - NABA as an alternative music radio station.

Since 2013, LTV and LR have a joint news portal for Latvian PSB in Latvian, Russian and English, named LSM.lv. Lacking further political support, as will be explained later, there has still been no reorganisation of the Latvian PSB into one legal person, after the decision of government (in 2011) to create a new Latvian PSM jointly working on TV, radio and the Internet, including mobile platforms.

LTV and LR are two state enterprises with one supervising external council, which, according to the law, is an independent authority (five members, chosen from among professionally or academically experienced candidates suggested by specialised NGOs in the fields of media, human rights, culture, education and science) who are elected by parliament for a term of five years, according to the political proportionality of the governing coalition. Elected candidates become members of the above-mentioned National Electronic Mass Media Council (the NEPLP) with an administrative capacity of only ten permanent staff members. However, the NEPLP in its single institution grasps too many functions, which partly create a conflict of interests for NEPLP members and which usually, in other European countries, belong at least to two different institutions. For example, the same NEPLP members, on one hand, as regulators must decide the administrative penalties for PSB organisations in case of violations of the law and, on the other hand, as the shareholders of these organisations, must satisfy their financial needs.

Firstly, it is the independent regulatory authority for audio-visual media services according to national law and the Audio-visual Media Services Directive of European Union. Such a regulator was set up in 1992 for the first time in Latvian history. Secondly, the NEPLP fulfils the tasks of a supervising council for LTV and LR as state enterprises, which are the biggest media enterprises in the country. It means also that the Council, in cooperation with LTV and LR, and together with the Public Consultative Council, established by the NEPLP as a body of experts from specialised 
NGOs on the fields of media, human rights, culture, education and science, elaborates the public remit for both public service broadcasters according to its own regulations based on the law.

At the same time, according to national Electronic Mass Media Law (2015) there is a legal option for the Council to provide up to $15 \%$ of the public service remit for commercial electronic mass media. The public remit includes themes, formats and budgets at the concept stage, including the audience, for each constant programme, but without deciding on concrete personalities, such as, for example, anchors, moderators, interviewers or participants of the programmes.

The Council also chooses the boards of LTV and LR. The editorial independence and the stability of PSB management, i.e. the autonomy of mass media sub-system in a modern society (Luhmann, 1996), to a large extent depend on the personal independence of the Council's members and the public service broadcaster's board members. They function as a buffer against the political and economic sub-systems of society, namely the pressure of narrow political and commercial interests, creating 'political facts,' but their independence is not guaranteed structurally enough. ${ }^{5}$

Thirdly, the NEPLP elaborates and approves media policy through its own National Development Strategy for the Electronic Mass Media Sector (the last five year strategy was for 2012-2017) which, according to the law, has the status of an external normative act, i.e. it is binding for actors within the industry.

5 This was demonstrated when the Saeima, the Parliament of Latvia, in an extraordinary session held on 8 July 2015 voted to dismiss me as chairman of the NEPLP (EPRA, 2015). The OSCE Representative on Freedom of the Media Dunja Mijatović on 30 June 2015 called for the media regulator's independence in Latvia to be respected. She spoke following a letter from Members of Parliament asking the Saeima to dismiss four members of the NEPLP. They were considered no longer suitable to hold their positions because of the alleged "loss of their good reputation" (OSCE, 2015). On this occasion Mijatović had "urged the members of the Latvian Parliament to carefully examine this proposal as the independence of national media regulators is a basic pre-condition for preserving and facilitating free media and free expression" (ibid.). The proceedings for firing the NEPLP board started on June 17 when the leaders of four Saeima factions, including the leading Unity Party, the Regional Alliance Party and the Greens and Farmers Alliance filed a submission for the dismissal of the entire council (LSM.lv, 2015). The decision of parliament was declared clearly "political" and was therefore overruled by the Administrative Regional Court on 23 December as "arbitrary" and "illegitimate" (Administratîvā rajona tiesa, 2015). If the Saeima in the meantime had approved a new member for the NEPLP, the court stated that I could not have been reinstated and that the violation of rights would have been irreversible (ibid.). 
As already mentioned, since 2011 the Latvian government has slowly been deciding the plans for the reform and creation of a unified PSM, not just PSB, i.e. including not only radio and TV broadcasting, but a multimedia approach, especially on the Internet platform, due to media convergence. Obviously, three problems must be solved in the process of creating the Latvian PSM.

Firstly, there is the administratively and financially difficult collaboration of two legal entities, independent enterprises with partly different organisational cultures, on three technological platforms: TV, radio and the Internet (e.g., see LSM.lv, common portal of Latvian PSM). Secondly, there exists a conflict of interests between the regulatory and PSM functions within the existing Council for PSB - the NEPLP. Thirdly, to date, in Latvian law the financial independence and stability of PSM have been legally secured by a single principle for PSB financing: the state subsidy for public service remit should not be less than in the previous year. This provision was also ignored by the government and the parliament for the first time since 2012, after the global financial crises and the increase in the Russian information war. Namely, the state subsidy for LTV and LR in 2016 is half a million euro less than in 2015 (Dimants, 2015a). There is no licence fee or earmarked tax for Latvian public service broadcasters, like in Lithuania where the financing of PSM has doubled through an earmarked rate of income (1.5\%) and excise (1.3\%) taxes since 2015 (Dimants, 2015b). However, meanwhile Latvian PSB remains underfinanced even in comparison to Estonian PSB: 22 million euro of state subsidies in Latvia versus 29 million euro of the same in Estonia.

\section{The concept of the new, unified Latvian PSM}

Following the initiative of Prime Minister Valdis Dombrovskis's government, since 2011 the NEPLP, in an open process, has drawn up and on 7 January 2013 approved a Concept for the new PSM (NEPLP, 2013) for a five year period (2013-2018). After internal contradictions in the ruling Unity Party and then the collapse of the governing coalition, this policy paper was ultimately not adopted by the government as its own policy planning document.

The critical point for the political leadership, leading them not to back the project, was the creation of a special new council for PSM where politicians wanted to have direct representation, which would be a step 
back in comparison to the current legal regulations and therefore was not supported by the NEPLP. Politicians, decision makers in government and parliament, both those in power and in opposition, are crucial stakeholders of PSB in Latvia, but they lack knowledge in the field of democratic media policy, and at the same time mostly represent a political culture with fragmented interests and ambitions, without the national consensus that is needed to strengthen the PSM (Beitika, 2015).

On one hand, according to Electronic Mass Media Law (2015) the Council has the authority to reorganise and restructure PSB organisations. On the other hand, Latvian PSB organisations are financed not by licence fees, but directly from the state budget, according to the law on annual state budgets and the respective political decisions. Two PSB organisations are directly mentioned in the law, and therefore decisions made by government and parliament are necessary for this reform.

Speaking about the achievements to date and prospects for the future, one must add the fact that after the economic crisis of 2012 serious improvements have occurred in finances and management for both Latvian public service broadcasters. The state subsidy for LTV and LR in 2014 conformed to the investment programme included in the above mentioned Concept and was agreed by the Ministry of Finance.

The Concept of the Council envisaged the step-by-step reorganisation of LTV and LR (until 2018) into a genuine, strong PSM: working for the public (the efficient synergy of existing and new channel brands on TV, radio and the Internet, also including social media), financed and supervised by the public. The main goal was to increase original content production according to content priorities, specific for development of PSM: (1) news $(+22 \%),(2)$ analytics $(+15 \%)$, (3) education and science $(+15 \%),(4)$ culture $(+7 \%),(5)$ children, teenagers and youth $(+10 \%)$.

The policy document drawn up by leading, national and international media experts and by stakeholders included, firstly, an original (Troxler, Süssenbacher, Karmasin, 2011, pp. 140-141) public value test (Donders, Moe, 2011) using annual audience polls (Gundlach, 2011, p. 15) for quantitative measuring of (1) the satisfaction of real PSM users and (2) their trust in PSM (Lowe, 2013). Such a public value test was introduced in 2014 , together with a new, internal system of programme quality measuring in LTV (Buholcs, 2016). That has been used to further develop the measuring of public value in Latvian PSM (ibid.; BICEPS 2015; Lowe, Martin, 2014, pp. 30-33) setting goals for each year also regarding (3) audience reach, (4) brand rankings and (5) increased financing for PSM, 
especially of the proportion of expenditure for content production within the budgets of PSM organisations.

Audience polls, made by GfK, show growing public trust in PSM: for LTV in 2014 in comparison to 2012 from $60 \%$ to $69 \%$, in 2015 to $74 \%$; for LR from $63 \%$ to $79 \%$, in 2015 to $84 \%$ (Buholcs, 2016). This constitutes a good basis for increased public support potentially pushing forward the appropriate governance and finance model for a strong Latvian PSM.

Secondly, the Concept foresees unifying PSM into a single legal entity by the synergetic concentration of human, financial and technical resources, with a special Council for PSM approved by parliament, but eliminating the influence of party politics from the Council (arising out of the principle of political proportionality), and at the same time structurally securing basic guarantees for editorial independence and pluralism both within the balanced managerial structure of PSM organisations itself (dividing programme planning and editorial production, etc.) us well in the Council's and consequently PSM boards' appointment and dismissal procedures. The last mentioned procedures were fixed according to constitutional values, especially to the separation of powers, and professional evaluation criteria for applicants with emphasis on the principles of PSM. In addition, in case of Council's appointment and dismissal the decisions should be based on parliamentary consensus, including both governing coalition and opposition into decision making, or at least on constitutional majority. Unfortunately, the political decisions of the government and the parliament in this regard are still lacking (Dimants, 2015a). In the Concept a self-regulatory PSM ombudsman institution would also have been created for organisational transparency (Chadwick, 2014, p. 14; Lowe, Martin, 2014, p. 34).

Thirdly, the step-by-step implementation of a special, public media tax to provide PSM was planned, and their leaving the advertising market at the same time. To date, income from advertising forms approximately one third of all the income of Latvian PSM.

\section{Main conclusions}

There is a clear interest of the lobbies of commercial electronic media and professional associations in the media field to support the withdrawal of PSM from the advertising market, as was done in Estonia (2007) and Lithuania (2015). Taking into account the public value development needs 
of Latvian PSM under conditions of a small media market (Moe, Van den Bulck, 2014, p. 62, 73), extra contributions from tax payers' money for PSM are necessary, as it was in Estonia and Lithuania.

To achieve this goal, a grand coalition among different stakeholders should be created, something which failed during the attempt to introduce the Concept. To be successful, this coalition, besides the NEPLP, LTV and LR itself, plus the Public Consultative Council, must include in one boat not only the decision makers in government and parliament and connected state institutions, like the new Department of Media Policy (since 2015 ) in the Ministry of Culture and the office of Prime Minister. It must also include the above-mentioned lobbies of commercial electronic media and professional associations in the media field. Therefore, a rational and pragmatic, solution-oriented approach is highly needed, based on finding common interests and respecting the specific social outcomes of PSM. Without shouting at each other, economic issues and policy evidence require that a balance be sought between those who argue for unfettered public service television, and those who argue that the market alone can meet the nation's audio-visual content needs (Picard, 20156).

Hence, at the end of day the National Electronic Mass Media Council was left alone with its limited instruments to create the political leadership necessary to strengthen the PSM. The Council used the establishing of new boards for LTV and LR to gain support for the Concept. In addition, joint projects of both PSB organisations were created on the initiative of the NEPLP, such as LSM.lv, multi-media LR5 - Pieci.lv, joint marketing activities, etc. This included the concept of a multi-media, Russian language channel of LTV, which was also not approved by the government (in 2015) because of the campaign by the National Alliance, one of the governing coalition parties and who had the Minister of Culture at the time, against promoting the use of the Russian language in Latvia.

${ }^{6}$ For example: "Commercial audio-visual providers operate with differing incentives than public service broadcasters and are less concerned about the social impact of their programming. Consequently, they tend to offer less original programming, less domestic programming, less culturally significant programming, and less programming dealing with social issues and public concerns. The ability to serve narrower audiences through non-broadcast means is increasing. Production of quality original content for them remains a challenge, however, because it tends not to be commercially viable or produces only limited income. The bulk of quality programming originates with production for broadcasters. [...] It is possible to use policy tools to achieve public service objectives outside of public service television, but the extent to which they are effective over time is uncertain." (Ibid.) 
Meetings and other communications with staff members of LTV and LR regarding the establishing of new PSM were organised by the Council, as well as numerous contacts and presentations to the politicians in government and parliament, at the same time intensively using policy planning procedures in cooperation with the relevant state institutions. The involvement of the interests of professional associations and commercial media was ensured in the Concept.

This process is well documented (Latvijas Sabiedriskais medijs) and was constantly accompanied by publications in the media, press releases, and on social media, press conferences, appeals of illustrious personalities (Memorands), annual reports and public value tests.

To get strong leadership in strategic communication (in broader sense of this term based on constitutional values and not on governmental public relations) of the Latvian democratic nation of citizens, and as a result growing acceptance of PSM by the public and politicians the following steps for strengthening PSM must be taken. The initiative of LTV to establish a common Baltic States' public service Russian language TV channel, as a brand and trustful communication platform for local Russian speakers oriented towards Europe and the West, would be one of such steps. That could be set up in the immediate future together with the new (since September 2015) Russian language channel of the Estonian public service television ETV+ and other international partners (Pomianowski, 2015, p. 68) if there were be enough expertise and political will among the decision makers.

\section{References}

Administratīvā rajona tiesa (2015), Spriedums Latvijas tautas vārdā, 23.12.2015, LSM.lv, http://www.lsm.lv/lv/raksts/latvija/zinas/tiesa-atcel-saeimas-lemumu-par-dimanta-atlaisanu-no-neplp.a161008/?rt=articles\&ac=attachDownload\&aid=161008\&id=277, 10.03.2016.

BBC (2004), Building public value: Renewing the BBC for the digital world, http:// downloads.bbc.co.uk/aboutthebbc/policies/pdf/bpv.pdf, 10.03.2016.

Beitika I. (2015), Public Service Media and Public Value: Analysis of Latvian Public Service Broadcasting System, Summary of Doctoral Thesis, University of Latvia, Riga.

Benigton J., Moore M. H. (eds.) (2011), Public Value: Theory and Practice, Palgrave Macmillan, Basingstoke.

BICEPS (2015), Radio apraide Latvijā - ekonomiskā analīze, Baltic International Centre for Economic Policy Studies, January 2015, Neplpadome.lv,http:// 
neplpadome.lv/lv/assets/documents/Petijumi/Radio_apraide_Latvija_2015 Jaunaka_versija.pdf, 10.03.2016.

Buholcs J. (2016), Atzinums par valsts SIA “Latvijas Televīzija” (LTV) valdes loceklı iepriekšèjā pilnvaru termiņā paveikto sabiedriskā pasūtījuma plānošanā un izpildē, 21.02.2016., Neplpadome.lv, http://neplpadome.lv/lv/assets/ documents/sabiedriskais\%20pasutijums/atzinums_par_ltv_24022016.pdf, 10.03.2016.

Chadwick P. (2014), Prologue, in: The Value of Public Service Media, eds. G. F. Lowe, F. Martin, Nordicom, University of Gothenburg, Göteborg.

Dimants A. (2008), The Latvian Public Service Broadcasting on the Way of Differentiation from the Political to the Media System, in: Abstracts: Media and Global Divides, IAMCR World Congress, Stockholm 20-25 July 2008, Stockholm University.

Dimants A. (2012), Medien in den baltischen Staaten nach dem EU-Beitritt-Das Fallbeispiel Lettland, "NORDEUROPAforum", Heft 1, http://edoc.hu-berlin.de/ nordeuropaforum/2012-1/dimants-ainars--7/PDF/dimants.pdf, 10.03.2016.

Dimants A. (2015a), Latvijas mediju politikas pamatnostādnes: viens solis uz priekšu, divi atpakal, "European Journalism Observatory", 01.12.2015, http://lv.ejoonline.eu/3680/mediji-un-politika/3680, 10.03.2016.

Dimants A. (2015b), Baltijas mediju veselība: skaiți runā, bet diagnoze nepiln̄̄ga, "European Journalism Observatory", 29.12.2015, http://lv.ejo-online.eu/3701/ mediju-zurnalistika/baltijas-mediju-veseliba-skaitli-runa-bet-diagnoze-nepilniga, 10.03.2016.

Donders K., Moe H. (2011), Exporting the Public Value Test: The Regulation of Public Broadcaster's New Media Services Across Europe, Nordicom, University of Gothenburg, Göteborg.

Electronic Mass Media Law (2015), http://neplp.lv/en/assets/documents/anglu/Electronic\%20Mass\%20Media\%20Law\%2012.2014.pdf, 10.03.2016.

EPRA (2015), Independence of NRAs: Chair of Latvian broadcasting regulator dismissed, European Platform of Regulatory Authorities, 09.07.2016, EPRA. org, http://www.epra.org/news_items/independence-of-nras-chair-of-latvianbroadcasting-regulator-dismissed, 10.03.2016.

Gundlach H. (2011), Public Value in der Medienökonomie, in: Public Value in der Digital- und Internetökonomie, ed. H. Gundlach, Herbert von Halem Verlag, Köln.

Habermas J. (1976), Was heißt Universalpragmatik?, in: Sprachpragmatik und Philosophie, ed. K. O. Apel, Suhrkamp, Frankfurt/M.

Habermas J. (1981), Theorie des kommunikativen Handelns, Bd. 1, Suhrkamp, Frankfurt/M.

Latvijas Sabiedriskais medijs (2013), 08.02.2013, Neplpadome.lv, http://neplpadome. lv/lv/sakums/sabiedriskie-mediji/sabiedriskais-pasutijums/jaunais-sabiedriskais-elektroniskais-medijs/, 10.03.2016. 
Lowe G. F. (2013), Developing Public Service Broadcasting in Latvia, 08.01.2013, Neplpadome.lv, http://neplpadome.lv/lv/assets/documents/JSEM/Gregory\%20Lowe.pdf, 10.03.2016.

Lowe G. F., Martin F. (eds.) (2014), The Value and Values of Public Service Media, in: The Value of Public Service Media, eds. G. F. Lowe, F. Martin, Nordicom, University of Gothenburg, Göteborg.

LSM.lv (2015), Court rules broadcast authority chairman to be reinstated, 23.12.2015, LSM.lv, http://www.lsm.lv/en/article/societ/society/court-rules-broadcast-authority-chairman-to-be-reinstated.a161018/, 10.03.2016.

Luhmann N. (1996), Die Realität der Massenmedien, 2, erw. Aufl., Westdeutscher Verlag, Opladen.

Memorands Latvijas sabiedriskā medija atbalstam (2013), 11.10.2013, Neplpadome.lv, http://neplpadome.lv/lv/assets/documents/JSEM/Memorands_gal_vers.doc, 10.03.2016.

Moe H., Van den Bulck H. (2014), Compering 'Public Value' as a Media Policy Term in Europe, in: The Value of Public Service Media, eds. G. F. Lowe, F. Martin, Nordicom, University of Gothenburg, Göteborg.

NEPLP (2013), Jaunā Latvijas sabiedriskā elektroniskā medija izveides koncepcijas detalizācija, Neplpadome.lv, http://neplpadome.lv/lv/assets/documents/sabiedriskais\%20pasutijums/KMKoncp_030613_LSEM.pdf, 10.03.2016.

OSCE (2015), OSCE Representative calls for respect of media regulator's independence in Latvia, Organization for Security and Cooperation in Europe, 30.06.2015, OSCE.org, http://www.osce.org/fom/167586, 10.03.2016.

Picard R. (2015), Shouting toward each other: Economics, ideology, and public service television policy, http://futureoftv.org.uk/wp-content/uploads/2015/09/ Robert-Picard1.pdf, 10.03.2016.

Pomianowski J. (2015), Viele Stimmen stärken, "Kulturaustausch", Ausgabe IV, http://www.kulturaustausch.de/index.phpid=5\&tx_amkulturaustausch pi $1 \%$ Bview $\% 5 \mathrm{D}=\mathrm{ARTICLE \& tx \_ amkulturaustausch \_ pi1 \% 5Bauid} \% 5 \mathrm{D}=22 \overline{4}$ 9\&cHash=b7e70816d5590f184de89d50205f4106, 10.03.2016.

Troxler R., Süssenbacher D., Karmasin M. (2011), Public-Value-Management als Antwort auf die Legitimationskrise und Chance für neue Strategien der Mehrwertgewinnung, in: Public Value in der Digital- und Internetökonomie, ed. H. Gundlach, Herbert von Halem Verlag, Köln. 
